\title{
PERENCANAAN KEUANGAN SYARI'AH DALAM UPAYA MENINGKATKAN KEMAMPUAN MANAJEMEN KEUANGAN KELUARGA PADA ANGGOTA MAJELIS TA'LIM
}

\author{
Ratna Anggraini ZR ${ }^{1)}$, Nuramalia Hasanah²), Adam Zakaria ${ }^{3)}$ \\ Prodi S1 Akuntansi, Fakultas Ekonomi, Universitas Negeri Jakarta \\ E-mail: r.anggrainizr_unj@yahoo.com
}

\begin{abstract}
Implementation of the sharia economy should be directed not only focused on banking activities. Sharia economic system is intended to provide benefits to the economy as a whole, including the management of family finances. Any religion in line with this concept is primarily Islamic as a mercy to the universe. This community service program aims to socialize sharia economy in family financial management, by taking mother lessons from learning in assemblies in Cawang Village. The result shows the spirit to immediately implement the sharia family financial planning.
\end{abstract}

Keywords: Sharia Economics, Family Financial Management

\section{ABSTRAK}

Implementasi ekonomi syariah saat ini harus diarahkan tidak hanya terfokus pada kegiatan perbankan. Sistem ekonomi syariah dimaksudkan untuk memberikan manfaat bagi perekonomian masyarakat secara keseluruhan termasuk pengelolaan keuangan keluarga. Agama apapun sejalan dengan konsep ini terutama Islam sebagai rahmat bagi alam semesta. Program pelayanan masyarakat ini bertujuan untuk mensosialisasikan ekonomi syariah dalam pengelolaan keuangan keluarga sebagai upaya untuk memperbaiki perencanaan keuangan rumah tangga, dengan mengambil pelajaran Ibu dari pembelajaran di majelis di Desa Cawang. Hasilnya Kegiatan tersebut menunjukkan semangat untuk segera menerapkan perencanaan keuangan keluarga syariah.

Kata Kunci: Ekonomi Syariah, Pengelolaan Keuangan Keluarga

\section{PENDAhUluan}

Pengelolaan keuangan keluarga dimasyarakat Indonesia, mayoritas masih menggunakan konsep tradisional. Ibu-Ibu rumah tangga khususnya sebagai 'manajer keuangan' keluarga, menggunakan dana yang dimiliki hanya berfokus pada kegiatan konsumsi perhari (belanja makanan dan minuman) atau perbulan (bayar listrik, telepon dll). Kondisi ini tidak membuat mereka berfikir untuk melakukan investasi membeli asset atau menabung untuk kegiatan lain,misal liburan atau pulang kampung.

Pengelolaan keuangan keluarga yang besifat tradisional ini, ditambah dengan pengaruh adanya keinginan untuk selalu membeli kebutuhan yang sebenarnya bukan menjadi kebutuhan pokok, yang meyebabkan munculya kondisi konsumerisme. Selalu ada dorongan untuk mengkonsumsi akibat pengaruh iklan dan lingkungan. Akibatnya masyarakat meningkatkan konsumsinya tanpa kesadaran yang penuh.

Mengkonsumsi memang merupakan aktivitas kehidupan manusia. Tapi, sekarang ini, dunia menawarkan beragam kebutuhan baru agar orang menkonsumsinya. Konsumerisme sebagai anak kandung kapitalisme telah merangsek sampai ke jantung masyarakat. Konsumerisme berhasil menciptakan kebutuhan baru di masyarakat. Pada kondisi ini, orang mengkonsumsi barang bukan lantaran butuh secara fungsional, melainkan karena tuntutan prestige (gengsi), status, maupun sekadar gaya hidup (life style). Ambil contoh, selalu mengganti telepon 
selular yang dimiliki dengan model terbaru,padahal tidak perlu.

Kalau kita kritis, arus konsumerisme inilah yang menyebabkan pola hidup boros.Di kalangan remaja, dikenal istilah 'borju' yang diplesetkan menjadi 'boros juajan.'Kita terlalu tanpa daya di hadapan tawaran konsumsi itu.Baudrillard menegaskan, kita tidak lagi mengontrol produk (objek), tetapi kitalah yang dikontrol dan diatur oleh produkproduk tadi. Kita dihanyutkan dalam ekstasi konsumsi dan gaya hidup dalam masyarakat konsumer. Di dalam gelombang konsumerisme ini, Baudrillard menyebut orang-orangnya sebagai 'mayoritas diam,' di mana masuk dalam jaringan laba-laba yang menjaring dan mengkonsumsi apa pun yang ada di hadapan mereka (Yasraf Amir Piliang,1999). Penerapan ekonomi syariah dewasa ini seharusnya diarahkan tidak hanya difokuskan untuk kegiatan perbankan, karena sistem ekonomi syariah ditujukan untuk memberikan kemashlahatan bagi perekonomian masyarakat secara keseluruhan termasuk pengelolaan keuangan keluarga baik muslim maupun non muslim, hal ini sejalan dengan konsep islam sebagai rahmatan lil alamin.

Penerapan ekonomi syari'ah pada pengelolaan keluarga dimulai dengan cara memdapakan nafkah dari sumber yang halal dan membelanjakannya kepada barang dan jasa yang halal pula. Bahkan jika dilihat lebih lanjut ekonomi syariah dalam pengelolaan keluarga juga tidak hanya pada sebatas konsumsi untuk diri sendiri atau keluarga sendiri, namun juga diintegrasikan dengan bagaimana konsumsi yg kita lakukan juga dapat berupa investasi,baik investasi didunia maupun diakhirat, dalam bentuk alokasi untuk tabungan syari'ah atau sedekah. Seperti kita ketahui pernah muncul fenomena 'Dimas Kanjeng Taat Pribadi', yang merugikan masyarakat karena mereka melakukan investasi, tidak hanya bertentangan dengan syari'at islam, namun juga tertipu karena tidak paham dengan konsep investasi.

Diintegrasikan dengan masalah sebelumnya, kegiatan pengabdian masyarakat ini diarahkan pada pelatihan pengelolaan keuangan syari'ah untuk ibu-ibu majelis ta'lim yang tentunya sudah lebih baik pemahaman keislamannya karena sering mengikuti pengajian rutin, agar dapat mengelola keuangan keluarga tidak hanya secara tepat,tapi juga baik sesuai dengan prinsip syari'ah

Berdasarkan uraian diatas, dapat diidentifikasi berbagai masalah sebagai berikut:

1. Bagaimana caranya agar masyarakat mengetahui dampak kesalahan dalam pengelolaan keuangan rumah tangga?

2. Bagaimana masyarakat mendapatkan pemahaman dalam pengelolaan keuangan rumah tangga yang syar'i ?

3. Bagaimana masyarakat dapat mengalokasikan pengelolaan keuangan kepada peluang investasi yan syar'i ?

Berdasarkan identifikasi masalah diatas, maka perumusan masalah dalam program pengabdian masyarakat ini adalah memasyarakatkan ekonomi syari'ah pada pengelolaan keuangan keluarga sebagai upaya meningkatkan perencanaan keuangan rumah tangga pada kelurahan Ibu-Ibu Majelis Ta'lim di Kelurahan Cawang.

\section{Manfaat Kegiatan}

Kompetensi yang diharapkan atas pelatihan ini adalah :

1. Ketrampilan peserta dalam perencanaan keuangan rumah tangga dengan baik sesuai dengan konsep syari'ah.

2. Ketrampilan peserta dalam berinvestasi sesuai konsep syar'iah.

Manfaat yang diperoleh atas pelatihan ini adalah : 
a. Peserta Pelatihan :

1. Peserta memahami proses pengelolaan keuangan rumah tangga.

2. Peserta memahami alternatif peluang investasi untuk menambah keuangan rumah tangga.

b. Tim Pengabdian Masyarakat :

1. Memberikan kontribusi pengetahuan kepada masyarakat dalam rangka memberdayakan masyarakat dan memcerdaskan bangsa sesuai dengan pengetahuan pengalaman yang dimiliki oleh instruktur.

2. Memahami aspek praktek pengelolaan keuangan rumah tangga di masyarakat membantu Pemerintah Daerah DKI dalam rangka program pemberdayaan masyarakat, lebih jauh hal ini akan membantu meningkatkan taraf hidup masyarakat.

\section{KAJIAN TEORITIK}

\section{A. Dasar-Dasar Pengelolaan Keuangan Keluarga Berbasis Syari'ah}

Prinsip perencanaan finansial secara islami ini diperkenalkan oleh Hijrah Strategic Advisory Group Sdn. Bhd (dalam Fauzi;2015), ada 7 prinsip utama. Jika prinsip ini dilaksanakan untuk merencanakan kebutuhan keluarga, tidak diragukan lagi kesejahteraan akan tercapai. 7 prinsip mengelola finansial secara islami adalah sebagai berikut:

\section{Pendapatan}

Pendapatan dalam Islam merupakan sumber yang harus dimiliki oleh rumah tangga muslim. Dalam mencari pendapatan haruslah sesuai dengan syariat Islam, harus halal dan toyyib. Rasulullah Saw. bersabda: "Sesungguhnya Allah itu baik dan hanya menerima yang baik-baik saja." (HR. Muslim). Pendapatan yang akan dibelanjakan untuk memenuhi kebutuhan pokok, seperti makan dan minum yang akan dikonsumsi, akan mengalir di dalam darah kita. Jadi usaha apa pun yang Anda lakukan haruslah halal, agar membawa berkah bagi keluarga dan terhindar dari murka Allah.

\section{Pengeluaran}

Pengeluaran masyarakat membutuhkan perencanaan yang baik berupa anggaran keuangan. Dalam merencanakan pengeluran dibuat pembagian kebutuhan pokok dan menyisihkan juga untuk berbagi kepada lingkungan yang membutuhkan.

\section{Perencanaan Jangka Panjang}

Perencanaan jangka panjang perlu dilakukan dalam kehidupan rumah tangga,misalnya untuk menentukan persiapan kuliah anak, untuk menangani kondisi darurat seperti sakit, untuk persiapan menjalankan ibadah Haji dan umrah dll. Untuk menghadapi kondisi yang aka datang perlu ada komitmen finansial yang baik, meskipun kita berkeyakinan manusia hanya bisa berencana, namun pada akhirnya Allah yang menentukan.

\section{Asuransi}

Asuransi merupakan bentu perlindungan diri dan harta kita. Bentuk- bentuk asuransi misalnya asuransi kesehatan dan asuransi kendaraan. Seorang muslim sebaiknya mengikuti asuransi yang berbasis syari'ah agar perlindungan yang dilakukan lebih berkah

\section{Pengelolaan Utang}

Islam membolehkan umatnya untuk melakukan utang terhadap kebutuhan yang mendesak, namun tidak dibolehkan jika utang tersebut mengandung unsur riba. Saat ini sudah banya bank syariah yang menawarkan utang mislnya untuk modal usaha,atau pembiayaan kendaraan.

\section{Investasi}

Umat islam dibolehkan untuk melakukan inverstasi,dengan tujuan untuk memanfaatkan dana berlebih yang dimiliki. Investasi tersebut bisa dalam bentuk emas, deposito ataupun saham yang berindex syariah, karena tidak 
mengandung unsur riba.Salah satu bentuk investasi lain yaitu untuk kegiatan usaha,misalnya membeli property untuk disewakan.

\section{Zakat}

Zakat merupakan rukun islam yang terakhir yang diwajibkan bagi umat islam jika sudah mencukupi nisab. Tujuan zakat untuk mensucikan harta yang memiliki dan untuk membantu sesama manusia. Dalam ekonomi syariah dirumah tangga zakat haruslah di perhitungkan sebagai pengeluaran rutin. Misalnya dari zakat profesi atau zakat pertanian dll.

\section{B. Anggaran Pendapatan Dan Belanja Dalam Rumah Tangga Berdasarkan Prinsip Islam}

Menurut Muhammad, prinsip penganggaran dan belanja dalam pengelolaan keuangan rumah tangga yang berdasarkan syari'ah adalah sebagai berikut:

1. Seimbang Antara Pendapatan dan Pengeluaran yang Bermanfaat

Istri tidak boleh membebani suami dengan beban kebutuhan dana di luar kemampuannya. Ia harus dapat mengatur pengeluaran rumah tangganya seefisien mungkin menurut skala prioritas sesuai dengan penghasilan dan pendapatan suami, tidak boros dan konsumtif. (QS. AlBaqarah:236, 286). Abu bakar pernah berkata: "Aku membenci penghuni rumah tangga yang membelanjakan atau menghabiskan bekal untuk beberapa hari dalam satu hari saja."

Islam menganjurkan umatnya untuk bekerja dan berusaha dengan baik .Islam juga menganjurkan agar hasil usahanya dikeluarkan untuk tujuan yang baik dan bermanfaat. Keluarga muslim dalam mengelola pembelanjaan, harus berprinsip pada pola konsumsi islami yaitu berorientasi kepada kebutuhan (need) di samping manfaat (utility) sehingga hanya akan belanja apa yang dibutuhkan dan hanya akan membutuhkan apa yang bermanfaat. (QS. Al-Baqarah:172, AlMaidah:4, Al-A'raf:32). Dalam berumah tangga, suami-istri hendaknya memiliki

29 | Jurnal Sarwahita Vol. 14 No. 01 Tahun 2017 konsep bahwa pembelanjaan hartanya akan berpahala jika dilakukan untuk hal-hal yang baik dan sesuai dengan perintah agama. Sabda Nabi shallallahu alaihi wa sallam: "Sesungguhnya tidaklah kamu menafkahkan suatu nafkah dengan ikhlas karena Allah kecuali kamu mendapat pahala darinya." (Muttafaq 'Alaih).

\section{Skala Prioritas Pengeluaran (Perlu/Needs Vs Ingin/Wants)}

Islam mengajarkan agar pengeluaran rumah tangga muslim lebih mengutamakan pembelian kebutuhan-kebutuhan pokok sehingga sesuai dengan tujuan syariat. Ada tiga jenis kebutuhan rumah tangga, yaitu:

\section{a. Kebutuhan primer,}

Kebutuhan primer merupakan nafkah-nafkah pokok bagi manusia yang diperkirakan dapat mewujudkan lima tujuan syariat (memelihara jiwa, akal, agama, keturunan dan kehormatan). Kebutuhan ini meliputi kebutuhan akan makan, minum, tempat tinggal, kesehatan, rasa aman, pengetahuan dan pernikahan.

\section{b. Kebutuhan sekunder,}

Kebutuhan sekunder merupakan kebutuhan untuk memudahkan hidup agar jauh dari kesulitan. Kebutuhan ini tidak perlu dipenuhi sebelum kebutuhan primer terpenuhi. Kebutuhan ini pun masih berhubungan dengan lima tujuan syariat.

\section{c. Kebutuhan pelengkap,}

Kebutuhan pelengkap merupakan kebutuhan yang dapat menambah kebaikan dan kesejahteraan dalam kehidupan manusia. Pemenuhan kebutuhan ini bergantung pada kebutuhan primer dan sekunder dan semuanya berkaitan dengan tujuan syariat.

Prioritas konsumsi dan pembelanjaan ini juga terkait dengan prioritas hak-hak yaitu hak terhadap diri (keluarga), Allah (agama), orang lain. Orang lain juga diukur menurut kedekatan nasab dan rahim, yang paling utama adalah orang tua kemudian saudara. (QS.AlAnfal:75) Aplikasi aturan-aturan di atas 
menuntut peran ibu rumah tangga untuk memperhitungkan pengeluaran rumah tangga secara bulanan berdasarkan tiga kebutuhan di atas, dengan tetap menyesuaikannya dengan pendapatan, sehingga rumah tangga muslim terhindar dari masalah-masalah perekonomian yang ditimbulkan atau sikap boros untuk hal yang bukan primer.

Islam mengharamkan pengeluaran yang berlebih-lebihan dan bermewah-mewahan karena dapat mengundang kerusakan dan kebinasaan. Allah berfirman: "Dan jika Kami hendak membinasakan suatu negeri, maka Kami perintahkan kepada orang-orang yang hidup mewah di negeri itu (suatu mentaati Allah) tetapi mereka melakukan kedurhakaan dalam negeri itu, maka sudah sepantasnya berlaku terhadapnya perkataan (ketentuan Kami), kemudian Kami hancurkan negeri itu sehancur-hancurnya." (QS. Al-Isra':16).

Selain itu, bergaya hidup mewah merupakan salah satu sifat orang-orang yang kufur terhadap nikmat Allah. Firman-Nya: "Pemuka-pemuka yang kafir di antara kaumnya dan yang mendustakan akan menemui hari akhirat (kelak) dan yang telah Kami mewahkan mereka dalam kehidupan di dunia..." (QS. Al-Mu'minun:33). Nabi juga sangat membenci gaya hidup mewah: "Makan, minum dan berpakaianlah sesukamu, sebab yang membuat kamuberbuatkesalahan itu dua perkara: bergaya hidup mewah dan berprasangka buruk."(HR. Ibnu Umar dan Ibnu Abbas).

3. Bersikap Pertengahan dalam Pembelanjaan

Islam mengajarkan sikap pertengahan dalam segala hal termasuk dalam perencanaan pembelanjaan, yaitu tidak berlebihan dan tidak pula kikir atau terlalu ketat. Sikap berlebihan adalah sikap hidup yang dapat merusak jiwa, harta dan masyarakat, sementara kikir adalah sikap hidup yang dapat menimbun, memonopoli dan menganggurkan harta. Kedua pola ekstrim dalam konsumsi itu memiliki mendekati sifat mubadzir. Firman Allah:

"Dan orang-orang yang apabila membelanjakan (harta), mereka tidak berlebih-lebihan, dan tidak (pula) kikir, dan adalah pembelanjaan itu) di tengah-tengah antara yang demikian.” (QS. Al-Furqon :67)

"Dan janganlah kamu jadikan tanganmu terbelenggu pada lehermu dan janganlah kamu terlalu mengulurkannya karena itu kamu menjadi tercela dan menyesal." (QS. Al-Isra:29) "danjanganlah kamumenghambur-hamburkan (hartamu) secara boros. Sesungguhnya pemborospemboros itu adalah saudara-saudara syaitan dan syaitan itu adalah sangat ingkar kepada Rabbnya." (QS. Al-Isra': 26-27)Sabda Rasul shallallahu 'alaihi wa sallam: "Allah akan memberikan rahmat kepada seseorang yang berusaha dari yang baik, membelanjakan dengan pertengahan dan dapat menyisihkan kelebihan untuk menjaga pada hari ia miskin dan membutuhkannya." (HR. Ahmad).

"Tidak akan miskin orang yang bersikap pertengahan dalam pengeluaran.” (HR. Ahmad).

Jika pembelanjaan kita telah sesuai dengan aturan-aturan Islam, Allah akan memajukan usaha kita serta melipatgandakan pahala dan berkah-Nya. Bahkan Allah akan memberikan kelebihan hasil usaha agar kita dapat menyimpan dan menabungnya untuk menjaga datangnya hal-hal yang tidak terduga atau untuk menjaga kelangsungan hidup generasi yang akan datang.

\section{METODE PELAKSANAAN \\ A. Kerangka Pemecahan Masalah}

Kerangka atau tahapan dalam pelatihan memasyarakatkan pengelolaan keuangan adalah sebagai berikut :

\section{Analisis Kebutuhan}

Berdasarkan diskusi yang dilakukan oleh tim pengabdian masyarakat pada program pelatihan ini, masyarakat khususnya ibu 
rumah tangga yang aktif dimajelis ta'lim memerlukan program pelatihan ini dengan pertimbangan :

a. Kurangnya pemahaman Ibu-Ibu majelis ta'lim khususnya terhadap pengelolaan keuangan secara syar'i sehing berdampak pada kebiasaan hidup yang salah.

b. Kurangnya pemahaman Ibu-Ibu majelis ta'lim terhadap pengelolaan dana sehingga masyarakat cenderung memanfaatkan penerimaannya untuk pengeluaran-pengeluaran yang tidak sesuai dengan kebutuhan keluarga sehingga cenderung mengarah pada sikap mubazir.

c. Kurangnya pemahaman masyarakat terhadap peluang-peluang berinvestasi guna membantu keuangan keluarga, sehingga berdampak pada keterlibatan praktek investasi ribawi.

d. Masih Minimnya Pembahasan tentang materi keuangan syari'ah di majelis ta'lim, khususnya majelis ta'lim IbuIbu.

2. Rancangan Instruksional

Dalam menentukan rancangan instruksional ini perlu dipertimbangkan aspek-aspek berikut :

a. Isi materi program pelatihan yang relevan dengan kebutuhan mereka. Tim ini telah memetakan kebutuhan materi keseluruhan bagi masyarakat yang dibagi dalam 3 materi pelatihan yang akan dijelaskan pada bagian materi pelatihan.

b. Latar belakang masyarakat misalnya pendidikan, pekerjaan utama, usia dan sebagainya.

c. Modul praktek yang digunakan pada pelatihan ini harus membantu peserta pelatihan memahami aspek teknis pengelolaan seperti alokasi sumber pendapatan dan penerimaan, penyaluran serta pemanfaatan investasi.

3. Tahap Pengembangan

Dalam rangka pengembangan program pelatihan memasyarakatkan pengelolaan keuangan ini, tim pengabdian masyarakat berupaya mengembangkan pelatihan ini baik dalam hal materi pelatihan, modul dan tanya jawab dalam bentuk yang relevan dengan aspek operasional pengelolaan dana, peminjaman kredit, sampai dengan pemanfaatan investasi yang sesuai dengan syariat islam.

\section{B. Realisasi Pemecahan Masalah}

Realisasi Pemecahan masalah pada kegiatan ini adalah sebagai berikut:

\section{Pelaksanaan}

Pelaksanaan program pelatihan ini pada bulan Mei bertempat di kelurahan Cawang Jakarta Timur. Waktu yang dialokasikan dalam pelatihan yaitu 4 jam pelatihan.

2. Evaluasi

Tim pengabdian masyarakat akan menyusun evaluasi terkait dengan pemahaman peserta terhadap materi pelatihan, pelaksanaan pelatihan secara keseluruhan untuk menampung kemungkinan dibutuhkannya pelatihan dengan materi lain dan tertibnya pelaksanaan program pelatihan ini.

3. Khalayak Sasaran

Peserta yang akan hadir sebanyak akan diwakili melalui peserta majelis ta'limibu-ibu yang ada dikelurahan cawang.

\section{Metode Yang Digunakan}

Metode pelatihan yang digunakan padaprogram pelatihan ini diharapkan dapat memberikan kemudahan kepada peserta pelatihan. Dalam pelatihan ini, metode yang digunakan adalah Metode Penjelasan, Praktek dan Tanya Jawab. Pada Metode Penjelasan, setiap instruktur menyampaikan materi terkait selama 90 menit kemudian dilanjutkan dengan sesi Praktek dan Tanya Jawab selama 60 menit. Instruktur direncanakan akan membuat power point slide dan modul ringkas praktek pelatihan yang akan dibagikan kepada peserta pelatihan sebelum program dimulai.

Alat bantu pelatihan seperti LCD proyektor juga digunakan agar peserta lebih 
mudah memahami materi pelatihan sementara instruktur lainnya juga mendampingi para peserta untuk memantau pertanyaanpertanyaan selama sesi praktek dan tanya jawab.

\section{HASIL DAN PEMBAHASAN A. Deskripsi Data}

Perkembangan Ekonomi Islam di Indonesia yang semakin meningkat dewasa ini, namun perkembangan ini masih belum dibarengi dengan meningkatnya pemahaman masyrakat tentang implimentasi ekonomi islam dalam kehidupan sehari-hari karena masih berfokus pada sektor perbankan. Aktivitas kajian keislaman yang ada dimasyarakat masih jarang menyinggung tentang urgensi pelaksanaan ekonomi islam dan bagaimana masyarakat melaksanakannya dalam kehidupan. Dengan melihat kondisi ini, peran dunia pendidikan sebagai isntitusi yang berkewajiban membersamai masyarakat semakin meningkat, sebagai bentuk dari tridarma peguruan tinggi sebagaimana ditetapkan oleh undang-undang.

Fakultas Ekonomi UNJ sebagai institusi pendidikan melaksanakan kegiatan tridarmanya melalui salah satu program pemberian pemahaman kepada masyarakat tentang ekonomi syari'ah. Program ini dilaksanakan di majelis ta'lim Ibu-Ibu, karena faktanya menunjukkan kegiatan majelis ta'lim, khususnya di DKI hampir ada disetiap kelurahan,bahkan mayoritas sudah ada disetiap RW dalam satu kelurahan. Melihat potensi ini, kami melaksanakan pengabdian pada masyarakat di majelis ta'lim,karena dalam pengamatan selama ini majelis ta'lim yang notabene merupakan wadah peningkatan pemahaman keislaman, masih jarang menyinggung soal ekonomi syari'ah.

Kegiatan Pelatihan bertujuan untuk
memberikan tengetahuan rang
perencanaan keuangan syari'ah dalam upaya
meningkatkan
perencanaankeuangan keluarga agar lebih

efektif dan efisien kepada anggota majelis ta'lim di Kelurahan Cawang.

Melalui kegiatan pelatihan ini para peserta tidak hanya diberikan materi-materi yang relevan dengan pemahaman perencanaan keuangan syari'ah, tetapi juga mendapatkan bimbingan dan arahan dalam implementasi keuangan dalam kehidupan sehari-hari

Dengan demikian diharapkan para peserta setelah mengikuti kegiatan pelatihan ini akan memiliki ketrampilan dan pemahaman dalam perencanaan ekonomi syari'ahsebagai upaya meningkatkan perencanaan keuangan sesuai dengan syari'ah islam.

Kegiatan ini telah berhasil dilaksanakan dengan baik dengan dihadiri oleh peserta yang terdiri dari anggota majelis ta'lim dikelurahan Cawang,Jakarta Timur.

\section{B. Analisis Teoritis}

Pelaksanaan pelatihan perencanaan keuangan syari'ah ini memerlukan strategi penyelenggaraannya untuk memaksimumkan efektifitas pelaksanaan kegiatan. Cara yang dipakai adalah dengan melakukan pendekatan kepada para peserta sebagai orang yang langsung berkaitan dengan permasalahan. Agar materi dapat dipahami dengan baik tentu harus dipilih metode penyampaian yang tepat, untuk itu akan digunakan metode pembelajaran simulasi dan tanya jawab. Metode ini akan merangsang peserta untuk tertarik dan berpartisipasi aktif dalam kegiatan pelatihan ini.

Pengetahuan akan tentang pemahaman perencanaankeuangan syari'ah bagi masyarakat, khususnya yang menganut ajaran islam, wajib dipahami agar aktivitas ekonomi masyarakat tidak bertentangan dengan nilainilai syari'ah yang membawa kemaslahatan dan keadilan.

Perencanaan keuangan syariah bagi masyarakat Indonesia yang mayoritas muslim dalam rangka mengarahkan aktivitas manajemen keuangan keluarga agar tidak 
menyimpang dari prinsi-pinsip syari'ah. Menurut Muhammad(2013) Seorang wanita shalihah akan selalu memberi saran kepada suaminya ketika hendak mencari rezki, "Takutlah kamu dari usaha yang haram sebab kami masih mampu bersabar di atas kelaparan, tetapi tidak mampu bersabar di atasapi neraka." Demikian pula sebaliknya suami akan berwasiat kepada istrinya untuk menjaga amanah Allah dalam mengurus harta yang dikaruniakan-Nya, agar dibelanjakan secara benar tanpa boros, kikir maupun haram. Firman Allah yang memuji hamba-Nya yang baik: "..Dan orang-orang yang apabila membelanjakan (harta), mereka tidakberlebih-lebihan, dan tidak (pula) kikir, dan adalah (pembelanjaan itu) di tengahtengah antara yang demikian." (QS. AlFurqan:67)

Tujuan pelatihan perencanaan keuangan syari'ah dalam upaya meningkatkan kemampuan manajemen keuangan keluarga pada anggota majelis ta'lim kelurahan cawang adalah :

1. Meningkatkan jumlah masyarakat, khususnya Ibu-Ibu yang cerdas finansial. Cerdas finansial ini maksudnya ibu rumah tangga yang memiliki kecerdasan finansial seharusnya dapat mengelola keuangan keluarganya dan memahami prinsip-prinsip muamalah maliyah (muamalah keharta bendaan) dan prinsip dasar sistem finansial Islami yang adil yang bersumber langsung dari Allah SWT.

2. Meningkatkan pemahaman Ibu-Ibu majelis ta'lim sebagai manajer finansial dan operasional keuangan keluarga.

3. Meningkatkan kemampuan Ibu-Ibu majelis ta'lim dalam mengembangkan harta yang dimiliki keluarga,sesuai dengan ketentuan syari'ah.

4. Meningkatkan kemampuan keuangan yang berguna untuk perencanaan, pengelolaan, dan pengendalian kegiatan dan keuangan keluarga secara efisien.

\section{Khalayak dan Sasaran}

33 | Jurnal Sarwahita Vol. 14 No. 01 Tahun 2017
Khalayak dan sasaran dari ini adalah Ibuibu majelis ta'lim yang ada dikelurahan cawang, sebanyak 23 orang.

\section{Keterkaitan}

Kegiatan ini terkait dengan instansi pendidikan,yaitu Universitas Negeri Jakarta yang membiayai kegiatan Pengabdian kepada Masyarakat yang dilaksanakan oleh dosendosen sebagai sebuah kewajiban atas Tridharma Perguruan Tinggi.

\section{PENUTUP}

\section{A. Kesimpulan}

Dalam era globalisasi serta tuntutan reformasi yang semakin meningkat, peran Ibu-Ibu sebagai perencanaan keuangan keluarga sangatlah strategis. Pelaksanaan peran yang diiringi dengan pemahaman manajemen keuangan syari'ah, menjadi penting dalam rangka mewujudkan masyarakat yang adil, makmur, sejahtera dan berkah. Kepentingan itu tidak hanya diperuntukkan untuk Ibu sebagai perencanaan keuangan, tetapi juga untuk kebutuhan pertanggungjawaban (accountability), sehingga dapat diketahui efesinsi dan efektifitas pengunaan keuangan untuk menghindari sifat mubazir.

Perkembangan ekonomi syari'ah tidaklah seiring dengan implimentasinya dikalangan masyarakat Indonesia yang mayoritas muslim. Penyebabnya adalah kurang sosialisasi dan pemahaman masyarakat tentang hal-hal yang berhubungan dengan fiqih muamalah, padahal semangat mempelajari islam semakin meningkat, namun materi-materi pengelolaan keuangan syari'ah khususnya dimajelis ta'lim Ibu-Ibu, masih belum di pelajari. Semakin besarnya pola konsumsi masyarakat yang mengarah pada sifat konsumerisme, adanya praktikpraktik investasi yang tidak sesuai dengan syari'ah, menuntut adanya peningkatan kemampuan praktis ibu-ibu dibidang keuangan sehingga dapat digunakan secara optimal, sebagai wujud kepedulian kepada masyarakat dan Tri Dharma perguruan tinggi, diadakannya Pelatihan Perencanaan 
Keuangan Syari'ah Dalam Upaya Meningkatkan Kemampuan Manajemen Keuangan Keluarga Pada Anggota Majelis Ta'lim Kelurahan Cawang.

Hasil yang dicapai dalam kegiatan pelatihan ini ialah peserta memiliki kemampuan yang lebih baik dalam perencanaan keuangan keluarga, khususnya yang sesuai dengan syari'ah Islam, sehingga harapannya dapat meningkatkan manajemen pengelolaan keuangan keluarga menjadi lebih baik. Disamping itu peserta merasa senang terhadap kegiatan tersebut,karena hal ini merupakan kegiatan baru dimajelis ta'lim,danterbukti dari kehadiran, dan ketekunan mereka mengikuti kegiatan sampai selesai dengan jumlah tetap dan tidak berkurang. Peserta juga terlihat antusias dalam memberikan tanggapan dan pertanyaan kepada pembicara yang memandu kegiatan tersebut.Dapat disimpulkan bahwa kegiatan ini sangat diminati masyarakat, bahkan ada yang mengusulkan untuk dapat dilaksanakan kegiatan lanjutan.

\section{B. Saran}

Pemberian materi dalam pelatihan ini harus dipastikan tidak bersifat monoton dan bersifat massal dan seragam. Disarankan jika memang memungkinkan harus dilakukan kegiatan yang merupakan kelanjutan dari kegiatan ini sehingga hasil yang diharapkan lebih mengena kepada pokok permasalahan, karena pelatihan ini tidak akan memperoleh hasil yang memuaskan jika tidak ditindaklanjuti.

Selain itu kegiatan ini memang harus dikembangkan sebagai wujud pengabdian kepada masyarakat dalam rangka peningkatan kualitas pemahaman masyarakat,khususnya tentang keuangan syari'ah. Untuk melaksanakan kegiatan yang efektif dengan hasil yang optimal dalam riil manfaatnya bagi peningkatan kesejahteraan masyarakat maka tidak terlepas dari dukungan dana yang memadai, agar kegiatan dapat dilakukan dalam jangka waktu yang lebih lama.
Diharapkan ke depan jumlah dana yang dianggarkan untuk kegiatan Pengabdian kepada Masyarakat bisa ditingkatkan jumlahnya.

\section{DAFTAR PUSTAKA}

Alqur'an, Departemen Agama RI.

Muhammad, Prof. 2013. Mengelola Keuangan Rumah Tangga Yang Islami, Artikel, Motivasi Diri. Diakses Maret 2017 dari PengusahaMuslim.com.

Fauzi, Dede. 2015. 7 Prinsip Mengelola Finansial Secara Islami ini Penting Untuk Anda Ketahui. Diakses Maret 2017 darihttp://odnv.co.id/

Zidan, Ummi. 2013. Peran Ibu Rumah Tangga Dalam Manajemen Finansial Keluarga. Diakses Maret 2017 dari https://uminyazidan.wordpress.com 